Revista de

Contabilidade e

Organizações

www.rco.usp.br
DOI: http://dx.doi.org/10.11606/issn.1982-6486.rco.2019.155596
Journal of

Accounting and

Organizations

\title{
An analysis of the relevant lawsuits in Brazilian companies: characteristics that influence the change in the probability of loss provision and contingent liabilities
}

Uma análise dos processos relevantes de empresas brasileiras: características que afetam a mudança na probabilidade de perda de provisões e passivos contingentes

Janaína da Silva Ferreira ${ }^{\text {a }}$, Suliani Rover ${ }^{\mathrm{a}}$

${ }^{a}$ Universidade Federal de Santa Catarina

Keywords

Provisions.

Contingent liabilities.

Litigations.

Probability of loss.
Palavras-chave

Provisões.

Passivos contingentes.

Litígios.

Probabilidade de perda.
Article information

Received: March 12, 2019

Accepted: December 6, 2019

Published: December 11, 2019

\begin{abstract}
The aim of this research is to identify characteristics that influence the change in the probability of provisions and contingent liabilities of Brazilian companies. This has been widely observed in specific industries that disclose more information on provisions and contingent liabilities, namely: oil, gas and biofuels, non-cyclical consumption and public utility. The data consisted of 6,194 observations, of which 2,058 lawsuits were mentioned in more than one period, and there were 228 changes in the probability of loss in the period from 2010 to 2016. A logistic regression model with panel data was applied, counting on 11 explanatory variables for the change in the probability of loss, which are divided into two perspectives: (a) characteristics of the companies and, (b) characteristics of the lawsuits. The results indicate that companies listed as 'New Market', ADR issuers, change the audit firms, respond to environmental, labor and civil lawsuits with large amounts in dispute, and have financial materiality in terms of risk expectation regarding losses and the duration of the legal process - are more likely to affect the change in the probability of loss. Conversely, the lawsuits in the first or superior instances are more likely not to change the probability of loss.
\end{abstract}

\section{Resumo}

O objetivo desta pesquisa é identificar características que influenciam a mudança na probabilidade de provisões e passivos contingentes de empresas brasileiras. Isso tem sido amplamente observado em setores especificos que divulgam mais informações sobre provisões e passivos contingentes, a saber: petróleo, gás e biocombustiveis, consumo não cíclico e utilidade pública. Os dados consistiram em 6.194 observações, das quais 2.058 ações foram citadas em mais de um período, e houve 228 alterações na probabilidade de perda no período de 2010 a 2016. Foi aplicado um modelo de regressão logística com dados em painel, com 11 variáveis explicativas para a mudança na probabilidade de perda, que são divididas em duas perspectivas: (a) características das empresas e (b) características dos processos judiciais. Os resultados indicam que as empresas listadas como 'Novo Mercado', emissores de ADR, que alteram as firmas de auditoria, respondem a processos ambientais, trabalhistas e civeis com grandes quantias em disputa, com materialidade financeira quanto a expectativa de risco em caso de perda e o tempo decorrido do processo têm maior probabilidade de afetar a mudança na chance de perda. Por outro lado, os processos que estão em $1^{a}$ instância ou em instâncias superiores têm maior probabilidade de não mudar a chance de perda, analisado pela significância e coeficiente negativo, esperados para esta pesquisa.

\section{Practical implications}

The judgment of the change in the likelihood of loss of contingent provisions and liabilities may cause distortions of current and future results. Knowing the characteristics that lead to a change in judgment assists in a more reliable analysis of the financial statements, the value of the company and its future cash flows. 


\section{INTRODUCTION}

Stakeholders are faced with the subjectivity of accounting standards that allow those preparing the financial statements to have alternative criteria that enable accounting choices and judgments about risks, such as off-balance sheet (OBS) information (Rosa, 2014; Losekann, Pereira, Lehnhart \& Löbler, 2018). One of the forms of OBS information is the legal proceedings to which the companies are involved, as plaintiffs or defendants, when they are classified as contingent liabilities. Brazilian companies report the risks considered relevant in the Reference Form (RF) required by the Securities and Exchange Commission of Brazil (CVM) (Gelbcke, Santos, Iudícibus \& Martins, 2018). The companies report the risk as probable, possible or remote, following the probability of loss classification provided in the technical pronouncement CPC 25 -provisions, contingent liabilities, and contingent assets, related to the International Accounting Standard (IAS) 37.

These classifications do not offer standards for accounting choices, and they depend on the manager's judgment. The resulting uncertainty in the probability of future losses may lead to ambiguities in the evaluation on contingency losses, and consequent inappropriate disclosure to the users (Nelson \& Kinney, 1997; Du \& Stevens, 2011; Losekann et al., 2018). For this reason, the regulations seek to guide the identification, adequate measurement, and disclosure of provisions and contingent liabilities, in order to ensure that stakeholders understand the nature, timing and value of such information (Comitê de Pronunciamentos Contábeis [CPC] 25, 2009). Holder, Karim and Woods (2013) highlight discussions on contingencies by regulators, with the possibility of contributions by interested groups. The agenda was the proposal for the contingent liabilities to be recognized in the balance sheet, being the measurement differentiated by the likelihood of loss in the lawsuits. However, interest groups were unfavorable to the proposal.

This provides for professional judgment of legal proceedings greater responsibility for the criteria for choosing the likelihood of loss. These should be aligned with the critical analysis of the lawsuits regarding their resolutions and values close to the actual amount to be disbursed, argument in the same direction as Daniels and Flesher (1991). The authors point out that the disclosure of these elements has been an accounting problem for decades and discuss about the materiality of these lawsuits, in terms of value and legal nature. Gonzalez and Silva Filho (2016) emphasize that the choices should be determined through legal particularities. Ribeiro, Ribeiro, and Weffort (2013) reinforce that after the analysis of the lawyers, there is the auditor's verification, and then it is submitted to the manager's validation.

The way the probability of loss is classified become a red flag for those who will benefit or be adversely affected by the decisions that impact the profit of the period. Doupnik and Richter (2004), Farias (2006) and Teixeira and Silva (2009) reflect on the impact of the classification on the financial statements, based on different perceptions of events. For Rosa (2014), the error in the classification of the contingent liabilities can distort the stakeholders' decisions. These distortions may be related to subjectivity in the interpretation of norms, especially when the probability of loss is presented verbally rather than in numbers. Even if the difficulty exists, it is necessary to interpret and disclose the information. Blacconiere and Patten (1994) found that not documenting information on provisions and contingent liabilities causes adverse reactions in the market.

In academic literature, provisions and contingent liabilities have been discussed observing the impact on the result when there is the inclusion of contingencies in the balance sheet (Rosa, 2014; Losekann et al., 2018). The literature has reflected on the uncertainty in judging the probability of loss due to differences in the norms (Capriotti \& Waldrup, 2005, Teixeira \& Silva, 2009). Also, there is a debate on the disclosure of this information in Brazil before the adoption of the international standards (Farias, 2006) and during the period of the conversion of the Brazilian to international standards observing the context before and after this process (Prado, 2014).

However, these studies do not specifically address the change in the probability of loss of a lawsuit. The studies of Rosa (2014) and Losekann et al. (2018) inspire the research on legal processes by classifying contingent liabilities as provisions and observing the negative impact in most companies, which raises awareness about the importance of trustworthiness of information on the classification of legal proceedings as probable, possible or remote probability of loss.

Observing the context of the relevance of provisions and contingent liabilities; the uncertainty in the judgment of this information, which can distort the financial statements; and the need to inform the stakeholders about the advances or setbacks of the lawsuits in which the companies are defendants, the research question explored in this article is: What characteristics affect the change in probability of loss of provisions and contingent liabilities of Brazilian companies? 
Brazil represents the emerging countries of the Americas in the report "Building Better Global Economic BRICs," that portrays countries with similar economic situation and development indices. Notwithstanding, Brazil is part of an important group of countries businesswise, but it is possible to observe lack of transparency, rules that are inconsistent and difficult to understand, an unstable tax system, difficulties in obtaining business licenses, and lack of clarity regarding property regulations (EAE Business School, 2018).

As for legislation, the legal insecurity in the country stands out. Although the Constitution seeks to provide stability in legal relations, the lack of predictability of the courts causes insecurity in investors. Regarding taxes, there are inconsistencies within the same instance. For example, the decision if the state tax ICMS is calculated together with the social security taxes PIS and Cofins; or the recent Brazilian labor reform, which is not clear on the application of the new provisions because the judiciary is averse to some of the changes approved (Macedo, 2018). The context of the Brazilian economy presented above must be taken into consideration to study the companies' choice when declaring the lawsuits, they consider relevant, and classifying their probability of loss.

As contributions, this research seeks to explore the change from contingency to provision and/or vice versa through the likelihood of loss as stated by the standard, especially in cases of subjective judgment. This can lead to misuse of the account, by mistake or for earnings management (Rosa, 2014), as opposed to the conceptual framework, where the information should be relevant and reliable (i.e. complete, neutral and free from error), as emphasized by Blacconiere and Patten (1994) to avoid negative market reactions.

\section{THEORETICAL FRAMEWORK}

\subsection{Judgement, Provisions and Contingent Liabilities}

The accounting practices in Brazil changed with Resolution CFC No. 1055/2005, which created the Accounting Pronouncements Committee (CPC), and with the technical pronouncements to clarify the provisions of laws 11638/2007 and 11941/2009. The main change lies in the subjectivity observed in the treatment of information, as it favors the essence over the format and the judgment of the professionals who prepare the financial statements.

Baptista (2009) explains that the discretion in the judgment aims to present the financial position and economic performance of the company so that managers and accountants feel directly responsible for these results (Losekann et al. 2018). Among the accounts that present subjectivity and judgment, the off-balance sheet stands out; it uses criteria of accounting choices to establish the best method according to the structure and operation of the company. Among these operations, users seek clarification on the disclosure of contingent liabilities. One of the difficulties is the lack of conformity between the FASB, IASB and SEC (Hennes, 2014).

In general, the information on liabilities and provisions are included in the Balance Sheet, while contingent liabilities are well-known as 'off-balance sheet' (OBS). In Brazil, the standards guiding preparers of financial statements regarding provisions and contingent liabilities is the technical pronouncement CPC25. The classification for the probability of loss provided by CPC 25 offers three likelihood outflows: "probable," "possible" and "remote."

This classification requires the judgment of an event, which may not be the most appropriate, considering that evaluations performed by different professionals may lead to different impacts on the financial statements (Teixeira \& Silva, 2009). It may also lead to an error in the interpretation of the norms in the classification of the probability of loss (Rosa, 2014) or to a tacit use of the norms to manipulate the accounting result (Baptista, 2009).

Also, the change in provision should be made whenever there is a change in the estimate observed in the reevaluation carried out at the closing of the balance sheet. In these cases, a provision may become a contingent liability or vice versa (Gonzalez \& Silva Filho, 2016). Legal advice is essential for the correct risk assessment (Gonzalez \& Silva Filho, 2016).

The studies of Rosa (2014), Jesus and Souza (2016), and Losekann et al. (2018) artificially reconfigured provisions and contingent liabilities to analyze the impact of reclassification. Rosa (2014) sought to identify the scenario of contingent liabilities and to measure the effects of their reconfiguration in the Brazilian context. The author then elaborated scenarios and analyzed effects on net income and equity. The main results indicate that the amount registered as provision affecting net income and equity is $12 \%$ of the sum of the lawsuits in the sample and that the expressiveness of contingent liabilities is high. Also, the disclosure in the explanatory notes to the financial statements regarding the items CPC 25 was on average $72 \%$, which shows partial compliance with the standards. 
Jesus and Souza (2016) analyzed the impacts of the recognition of contingent liabilities on the economic situation in Brazilian companies audited by the big four. Of the 50 companies surveyed, $93 \%$ had high disclosure of contingent liabilities of civil, fiscal and labor nature. On the other hand, only one company disclosed environmental contingent liability. Also, their results show that recognizing contingent liabilities, both in the Balance Sheet and Income Statement, most companies reported losses and a negative equity.

Losekann et al. (2018) studied the situation of contingent liabilities for companies included in the Corporate Governance levels and their effects on the reclassification of amounts of legal proceedings. The authors elaborated five scenarios: optimistic, partially optimistic, moderate, partially moderate and pessimistic. The main results indicate that $76 \%$ of the companies are in the new market. By reclassifying the amounts of contingent liabilities as provisions, companies present losses when comparing the percentage with the profit and the equity.

In the legal context, Ribeiro, Ribeiro, and Weffort (2013) explain the Brazilian tax legislation framework referring to the period of high inflation rates, which caused the government to issue economic packages seeking to adjust the economy and lower the inflation rates. Thus, fiscal adjustment laws were designed to increase tax collection to balance public accounts, many of which are contested as to constitutionality, leading to difficult and time-consuming legal disputes.

Gonzalez and Silva Filho (2016, p.28) explain that the analysis of legal risks should be determined by legal peculiarities, such as "the factual and evidential elements, the subject to be defended, the jurisprudence on the subject under discussion." For Lima, Menezes Junior, and Rodrigues (2017, p.6) differential treatment must be given to lawsuits that are subject to binding precedents, because they "lack of certainty about a positive result, even though the 'patrons' of the cause, or those who indicated chances of success, have evaluated the proceedings in a positive way."

Research on the subject of provisions and contingent liabilities shows several methods utilized as surveys (Doupnik \& Richter 2004; Teixeira \& Silva, 2009); archival (Jesus and Souza, 2016; Lima et al. 2017; Prado, 2014; Rosa, 2014); scenario simulation (Losekann et al. 2018; Rosa, 2014); interviews (Ribeiro, Ribeiro \& Weffort, 2013); regression (Hennes, 2014) and disclosure level (Castro, Vieira \& Pinheiro, 2015). The contributions made here have wide applicability with a different focus, also contribute to the advancement of debate of the topic.

\subsection{Hypothesis development}

\subsubsection{Company-level Characteristics}

\section{Corporate governance}

Jensen and Meckling (1976) dealt with agency conflicts in organizations resulting from the separation between the company's ownership (i.e. principal) and its management (i.e. agent), and corporate governance can be used by the principal to overcome a lack of information about the agent's performance. Silveira and Barros (2008) analyzed the determinant factors of corporate governance, finding that the greater the power of the controlling shareholder, the worse the quality of the governance. Also, larger companies that issue American Depositary Receipts (ADR) and present better performance are the ones with better corporate governance. The Brazilian stock exchange (B3) has elaborated corporate governance segments divided by the levels: New Market, Level 1 of Corporate Governance, Level 2 of Corporate Governance, Bovespa More, Bovespa More Level 2. The highest level is 'New Market'. Thus, regarding the probability of loss in these legal lawsuits, the first hypothesis in this study is: lawsuits.

$\mathbf{H}_{\mathbf{1}}$ : Listed in the 'New Market' is positively related to the change in the probability of loss in the relevant 


\section{Internationalization}

Regarding external visibility, Brazilian companies that choose to issue American Depositary Receipts (ADR) have to comply with strict and differentiated regulations imposed by the Securities and Exchange Commission (SEC). Castro, Vieira, and Pinheiro (2015) noted that there is asymmetry in the information on contingent asset and liability on the B3 and NYSE disclosed by the same Brazilian company. Piccioni, Sheng and Lora (2012) found that foreign fund managers investing in Latin America prefer companies that have a higher level of visibility to reduce information asymmetry, ADR issuers, analyst coverage and if the company export more than it imports. On the contrary of the behavior of national managers.

Santana (2013) identified that the internationalized companies, which are in the top positions of the "Ranking da Fundação Dom Cabral", are the ones that use more OBS operations. Considering that international visibility is a characteristic that directly or indirectly affects the investors decision, the second hypothesis of this study is:

$\mathbf{H}_{2 \mathbf{a}}$ : ADR issuer is positively related to the change in the probability of loss of the relevant lawsuits.

$\mathbf{H}_{\mathbf{2}}$ : The internationalization index is positively related to the change in the probability of loss of the relevant lawsuits.

\section{Industry regulation}

Industry regulation have specific disclosure rules that suggest a higher level of information and lower risk (Moreira, 2013). Prado (2014) sought to identify the potential risks of disclosing information about provisions and contingent liabilities of the energy industry, especially after the modernization of accounting regulations and the industry privatization. The author observed a learning curve according to the evolution of the legislation imposed by the regulatory agency (ANEEL) and started to disclose more information over time. Therefore, regulation can be a motivation to change the probability of loss of the lawsuits. However, it is not possible to regulate the judgment of the managers and, therefore, it is crucial to test the relation of these companies with the probability of loss:

$\mathbf{H}_{3}$ : Industry regulation is positively related to the change in the probability of loss of relevant lawsuits.

\section{Audit}

Jesus and Souza (2016) simulated the recognition of contingent liabilities as a provision and analyzed the impacts on the economic situation of the companies audited by the big four. The sample is intentional and formed of 50 companies that have contingent liabilities. Among these companies, ten had losses, and none had unfunded liabilities. After the simulation, 30 companies started to present losses and three, unfunded liabilities. The authors found that $60 \%$ of the companies in the sample would have their profits reduced by $100 \%$. In addition, Jesus and Souza (2016) verified that each audit firm better identifies specific items of the CPC 25 (2009). Given the specificities of each company and the power of judgment inherent to the profession, the following research hypothesis is elaborated: lawsuits.

$\mathbf{H}_{4}$ : Changing the audit firm is positively related to the change in the probability of loss of the relevant

\section{Variation in the net profit}

The studies of Rosa (2014), and Losekann et al. (2018) discuss the possibility of earings management or inconsistencies in the interpretation of norms that have subjective characteristics. Therefore, it is critical to test whether the variation of the companies' net profits implies a favorable measure for the change in the probability of loss of the lawsuits.

Companies with losses in the previous year could reverse provisions to improve profits or losses. Also, depending on the year (whether it is a period of recession or not), above average result may lead to the practice of identifying other amounts to be provisioned as a form of tax planning. In this sense, another hypothesis is:

$\mathbf{H}_{5}$ : The change in the result (earnings or net profit) is positively related to the change in the probability of loss of the relevant lawsuits. 


\section{Size}

Regarding company size, Firth (1979) discussed the reasons that lead larger companies to disclose more financial information.In order to outsource information, it is necessary to monitor data in the internal environment

and listing on the stock exchange, access to funding of resources.. Therefore, if larger companies seek to disclosure more information, they are probably willing to assess and reassess their provision and contingent liabilities, enumerating the changes in the probability of loss whenever necessary, leading to the following research hypothesis:

$\mathbf{H}_{6}$ : The size of the firm is positively related to the change in the probability of loss of the relevant lawsuits.

\subsubsection{Lawsuit-level Characteristics}

\section{Type of Lawsuit}

The variables related to the lawsuits are those inherent to legal disputes, to the document and to the proceedings. Ribeiro, Ribeiro, and Weffort (2013) analyzed the context of tax legislation in Brazil, and discussed the legal disputes arising from unconstitutional laws, making the lawsuits burdensome and time-consuming. The lawsuits are classified according to their nature, such as tax/fiscal, labor, civil and environmental (Jesus \& Souza, 2016). There is a possibility that the nature of the lawsuits may influence the change in the probability of loss. In this way, the following hypotheses were elaborated, and the lawsuits classified as "others" were used as a basis in the statistical model: lawsuits.

$\mathbf{H}_{7 \mathbf{a}}$ : The type of labor lawsuit is positively related to the change in the probability of loss of the relevant lawsuits.

$\mathbf{H}_{7 \mathbf{b}}$ : The type of tax lawsuit is positively related to the change in the probability of loss of the relevant

$\mathbf{H}_{7 \mathbf{c}}$ : The type of environmental lawsuit is positively related to the change in the probability of loss of the relevant lawsuits. lawsuits.

$\mathbf{H}_{7 \mathbf{d}}$ : The type of civil lawsuit is positively related to the change in the probability of loss of the relevant

$\mathbf{H}_{7 \mathrm{e}}$ : The type of regulatory lawsuit is positively related to the change in the probability of loss of the relevant lawsuits.

\section{Lawsuit Value}

Gleason and Mills (2002) found that the probability of tax contingency disclosures increases when a large amount is involved, and the amounts considered intangible are not indicated, regardless of their probability of loss. Hennes (2014) analyzed the same elements, but from the perspective of the labor contingency. She verified that the greater the probability of loss and the amounts involved, the greater the qualitative disclosures. Thus, the greater the volume of resources requested in a lawsuit, the greater the legal team's persistence to win the lawsuit, due to the impact on the company. Therefore, the following hypothesis is proposed:

$\mathbf{H}_{\mathbf{8}}$ : The amount involved in the lawsuit is positively related to the change in the probability of loss of the relevant lawsuits.

\section{Lawsuit Duration}

It is possible to observe that the longer the lawsuit lasts, the greater the chances of a change in the probability of loss. When analyzing the point of view of Ribeiro, Ribeiro, and Weffort (2013) on the judicial system, it is noted that the gaps in the legislation result in time-consuming lawsuits, in which companies appeal numerous times and postpone the outcome for long periods, administering the resources of the company using legal mechanisms. It is considered that time influences the change in the probability of loss of lawsuits, and the longer the process start time, the greater the chance of changing the probability of loss. The following hypothesis is therefore adopted: 
$\mathbf{H}_{\mathbf{9}}$ : Lawsuit duration is positively related to the change in the probability of loss of the relevant lawsuit.

\section{Materiality}

Gleason and Mills (2002) studied the factors the companies use to disclose and record tax contingencies. The results show that the probability of disclosure of contingency increases when a large amount is involved, and that the amounts considered intangible are not indicated, regardless of their probability of loss. Hennes (2014) analyzed whether the disclosure of labor contingencies provides useful assessments to stakeholders. She found that companies disclose more qualitative than quantitative information, especially in litigations where there is a greater probability of loss or involving higher amounts. In order to verify if the financial materiality influences the change in the probability of loss of lawsuits of Brazilian companies, the following hypothesis is presented:

$\mathbf{H}_{10}$ : The financial materiality of the lawsuits is positively related to the change in the probability of loss of the relevant lawsuits.

\section{Instances}

In each procedural sphere are defined instances to delimit the stage of the process. The discussion begins at the lower court, with modest expectation of resolution. The intermediate stages are the 2nd and 3rd where there are possibilities of changes on the subject discussed, especially from the result of the previous decision. Finally, there is the superior court, where normally all procedural evidence has already been presented and the result is awaited. Considering these aspects, the following research hypotheses are elaborated, being the instances classified as "others" the basis of the hypotheses:

$\mathbf{H}_{11 \mathbf{a}}$ : The lawsuit in the first instance is negatively related to the change in the probability of loss.

$\mathbf{H}_{11 \mathrm{~b}}$ : The lawsuit in a superior instance is negatively related to the change in the probability of loss.

For the intermediate instances, the research hypotheses are:

$\mathbf{H}_{11 \mathrm{c}}$ : The lawsuit in the second instance is positively related to the change in the probability of loss.

$\mathbf{H}_{11 \mathbf{d}}$ : The lawsuit in the third instance is positively related to the change in the probability of loss.

\section{METHODOLOGY}

\subsection{Research sample}

The sample was collected among the companies listed in B3, and the selection was based on the volume of disclosure of provisions and contingent liabilities. According to Rosa (2014) among the sectors of the Brazilian stock exchange that most disclosure this information, are: oil, gas, and biofuels (11 companies); non-cyclic consumption ( 24 companies) and public utility (24 companies). Companies that are listed as BDR were excluded from the sample because they did not present the Reference Form. More information can be found in the Appendix.

\subsection{Data collection and analysis}

The study classified the lawsuits disclosed by the companies listed in the B3, considering the period of analysis the beginning of the disclosure of the RF, from 2010 to 2016 . The data collected from the RF's "Item 4.3 to 4.7 - Risk Factors" are: year of the RF, number of the lawsuit; parties to the lawsuit; instance of the legal process; the amount involved and provisioned; the probability of loss; year of commencement; and materiality. It is important to highlight some characteristics found in the lawsuits observed during the data collection. The companies do not entirely standardize the numbers of the lawsuits. The instances were tabulated so all the lawsuits that already passed by first to third instances were considered in the group 'superior instances'. When the company reported any other information instead of the instance, the study classified it in the group 'others'. 
Most companies did not estimate the amount of the lawsuit or maintain a standard in presenting traditional or updated amounts. It was possible to see in the classification of the probability of loss that some companies chose their classifications, such as active, very probable, no risk, not applicable, improbable. Some of them substituted the classification for information about the end of the lawsuit. Regarding the starting date of the lawsuit, the study found discrepancies in information about the same lawsuit. Some of the companies informed only the year, or month and year. In these cases, it was considered January 1 of that year. Other lawsuits reported without the starting date were tabulated as zero years. To establish the number of lawsuits, they were tabulated considering the amount disclosed as the probability of loss.

Also remarkable are the lawsuit that, despite being disclosed in two or more periods, do not inform the probability of loss in all of the years analyzed. In these cases, because it is not possible to identify if there was a change in the probability of loss, the probability of the previous year was maintained. However, in cases where there was no probability of loss reported during the years in which it was informed, the lawsuit was excluded from the sample.

\subsection{Constructs of the research hypotheses}

The information collected in RF were tabulated with the support of Excel ${ }^{\circledR}$ spreadsheets. Also, possible factors influencing the change in the probability of loss of the lawsuits were identified in the literature. Table 1 shows the constructs that guide the research.

Table 1. Constructs guiding the research

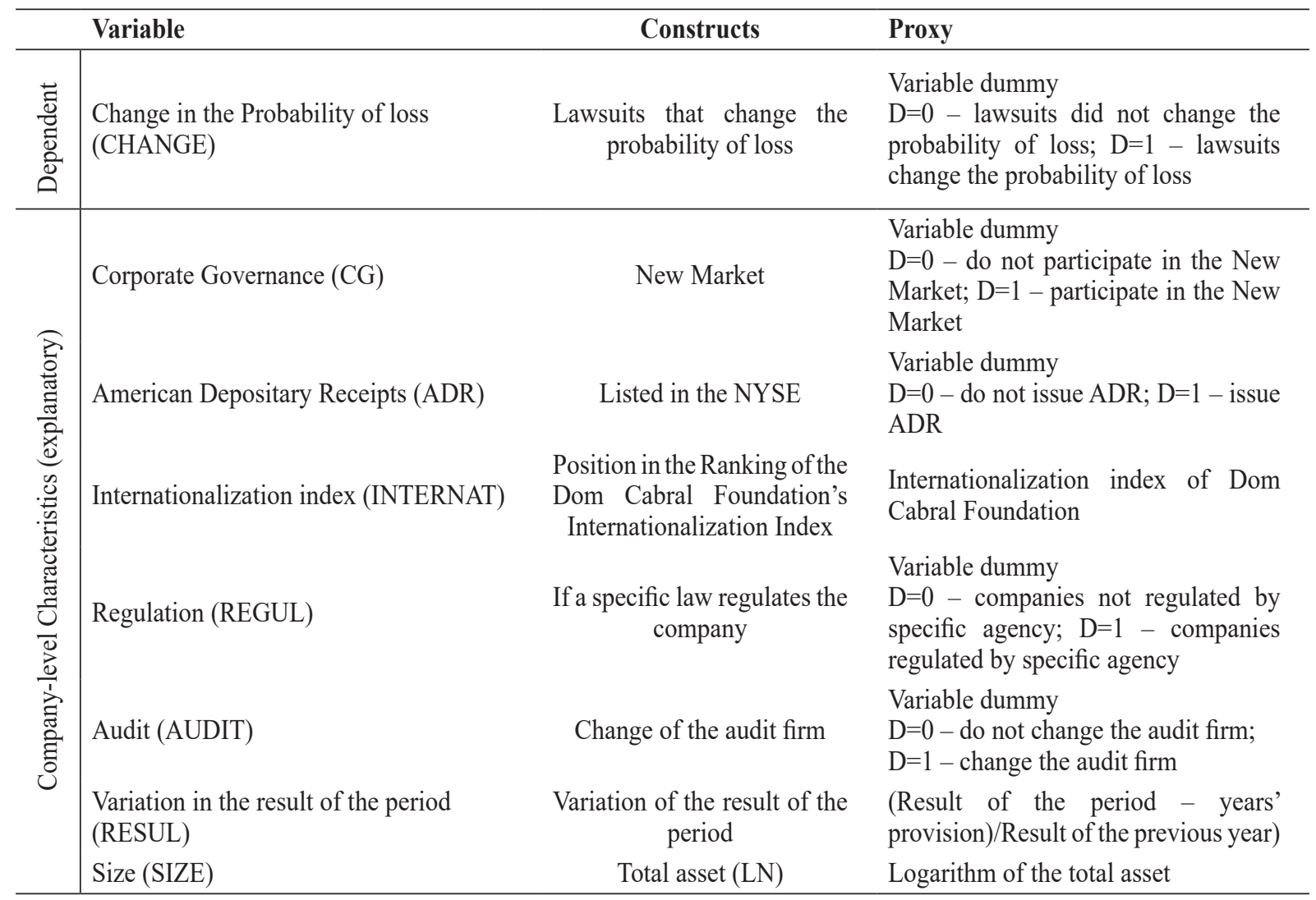

Source: Research data. 
Table 1. Constructs guiding the research (continued)

\begin{tabular}{|c|c|c|c|}
\hline \multirow{12}{*}{ 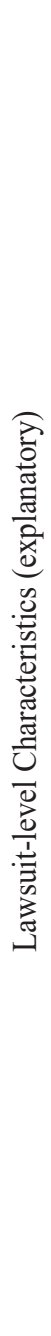 } & Type (LAB) & $\begin{array}{c}\text { Classification of the lawsuit } \\
\text { by the company }\end{array}$ & $\begin{array}{l}\text { Variable dummy } \\
\mathrm{D}=0 \text { - other types; } \mathrm{D}=1-\text { type labor }\end{array}$ \\
\hline & Type (TAX) & $\begin{array}{l}\text { Classification of the lawsuit } \\
\text { by the company }\end{array}$ & $\begin{array}{l}\text { Variable dummy } \\
D=0 \text { - other types; } D=1-\text { type tax }\end{array}$ \\
\hline & Type (ENV) & $\begin{array}{l}\text { Classification of the lawsuit } \\
\text { by the company }\end{array}$ & $\begin{array}{l}\text { Variable dummy } \\
\mathrm{D}=0-\text { other types; } \mathrm{D}=1-\text { type } \\
\text { environment }\end{array}$ \\
\hline & Type (CIV) & $\begin{array}{l}\text { Classification of the lawsuit } \\
\text { by the company }\end{array}$ & $\begin{array}{l}\text { Variable dummy } \\
D=0 \text { - other types; } D=1-\text { type civil }\end{array}$ \\
\hline & Type (REG) & $\begin{array}{l}\text { Classification of the lawsuit } \\
\text { by the company }\end{array}$ & $\begin{array}{l}\text { Variable dummy } \\
\mathrm{D}=0-\text { other types; } \mathrm{D}=1-\text { type } \\
\text { regulatory }\end{array}$ \\
\hline & Amount (AMOUNT) & $\begin{array}{l}\text { Amount of the lawsuit in } \mathrm{R} \$ \\
\text { (LN) }\end{array}$ & Logarithm of the lawsuit amount \\
\hline & Duration of the lawsuit (TIME) & $\begin{array}{c}\text { Time, in years, since the start } \\
\text { of the lawsuit }\end{array}$ & Duration of the lawsuit \\
\hline & Materiality (MATERIAL) & $\begin{array}{l}\text { Disclosure, by the company, } \\
\text { about the financial impact }\end{array}$ & $\begin{array}{l}\text { Variable dummy } \\
D=0-\text { do not have financial } \\
\text { materiality; } D=1-\text { have financial } \\
\text { materiality }\end{array}$ \\
\hline & First Instance (INST1) & Instance of the legal process & $\begin{array}{l}\text { Variable dummy } \\
\mathrm{D}=0-\text { other instances; } \mathrm{D}=1-\text { first } \\
\text { instance }\end{array}$ \\
\hline & Second Instance (INST2) & Instance of the legal process & $\begin{array}{l}\text { Variable dummy } \\
D=0-\text { other instances; } D=1-\text { second } \\
\text { instance }\end{array}$ \\
\hline & Third Instance (INST3) & Instance of the legal process & $\begin{array}{l}\text { Variable dummy } \\
\mathrm{D}=0 \text { - other instances; } \mathrm{D}=1-\text { third } \\
\text { instance }\end{array}$ \\
\hline & Superior Instance (INSTSUP) & Instance of the legal process & $\begin{array}{l}\text { Variable dummy } \\
\mathrm{D}=0 \text { - other instances; } \mathrm{D}=1 \text { - superior } \\
\text { instances }\end{array}$ \\
\hline
\end{tabular}

Source: Research data.

\subsection{Techniques of analysis}

The collection of data on the lawsuits allows the use of the logistic regression model with panel data. The model overall efficiency was tested using the confusion matrix, where a cutoff of $5 \%$ presented correctly classified $73.72 \%$ and a cutoff of $50 \% 96.32 \%$. The Roc curve was generated and the area below it is 0.7403 , an acceptable parameter. In order to define the most suitable data probability estimator for panel logistic regression, the Hausman test was used to decide between random or fixed models. With the result of Prob $>\operatorname{chi} 2=0.0727$, the null hypothesis is not rejected, indicating the random model as the most appropriate.

Based on the variables presented in Table 1, the model that aims to identify the characteristics that affect the change in the probability of loss of provisions and contingent liabilities of Brazilian companies is described in equation 1 :

$$
P\left(\text { CHANGE) } 1 /\left(1+e^{-g(x)}\right)\right.
$$

Where:

$$
\begin{aligned}
& g(x)=\beta_{0}+\beta_{1} C G_{i t}+\beta_{2} A D R_{i t}+\beta_{3} I N T E R N_{i t}+\beta_{4} R E G U L_{i t}+\beta_{5} A U D I T_{i t}+\beta_{6} R E S U L_{i t}+\beta_{7} S_{I Z E_{i t}}+\beta_{8} L A B_{i t}+\beta_{9} T A X_{i t} \\
& +\beta_{10} E N V_{i t}+\beta_{11} C I V_{i t}+\beta_{12} R E G_{i t}+\beta_{13} \text { VAL L }_{i t}+\beta_{14} \text { TIME }_{i t}+\beta_{15} \text { MATERIAL }_{i t}+\beta_{16} \text { INSTI }_{i t}+\beta_{17} I N S T 2_{i t}+\beta_{18}^{l t} I_{1 N S T 3_{i t}}+ \\
& \beta_{I g} I N S T S U P_{i t}+\mu_{i t}
\end{aligned}
$$

Where:

CHANGE: Binary variable, where it is assigned 1 (one) when the changes the probability of loss of the relevant lawsuit $\mathrm{i}$, related to the provision and contingent liability in the period $\mathrm{t}$ - and $(0)$ zero when it does not change; 
$\beta_{0}$ : Regression coefficient;

From $\beta_{1}$ to $\beta_{19}$, they are explanatory variables where: period t;

$C G_{i t}$ dummy: binary referring to the different levels of corporate governance of the company $\mathrm{i}$, in the

$A D R_{i t}$ dummy: binary of issuing the American Depositary Receipts by company $\mathrm{i}$, in the period $\mathrm{t}$;

INTERN $N_{i t}$ the position of the company $\mathrm{i}$, in the period $\mathrm{t}$, in the ranking of the Internationalization Index of the Dom Cabral Foundation;

$R E G U L_{i t}$ dummy: regulation of the company $\mathrm{i}$, in the period $\mathrm{t}$;

$A U D I T_{i t}$ dummy: binary of changing audit firm of company i, in the period t;

RESULT $_{i t}$ : variation of the result of the company $\mathrm{i}$ in the period $\mathrm{t}$;

$S I Z E_{i t}:$ Ln of the size of the company $\mathrm{i}$, in the period $\mathrm{t}$;

$L A B_{i t}$ dummy: binary of the type of labor lawsuit of the company $\mathrm{i}$, in the period $\mathrm{t}$;

$T A X_{i t}$ dummy: binary of the type of tax lawsuit of the company $\mathrm{i}$, in the period $\mathrm{t}$;

$E N V_{i t}$ dummy: binary of the type of environmental lawsuit of the company i, in the period $\mathrm{t}$;

$C I V_{i t}$ dummy: binary of the type of civil lawsuit of the company $\mathrm{i}$, in the period t;

$R E G_{i t}$ dummy: binary of the type of regulation lawsuit of the company $\mathrm{i}$, in the period $\mathrm{t}$;

$A M O U N T_{i t}$ : the amount of the lawsuit $\mathrm{i}$, in the period $\mathrm{t}$;

$T I M E_{i t}$ indicates the duration of the lawsuit $\mathrm{i}$, in the period $\mathrm{t}$;

MATERIAL $L_{i t}$ dummy: binary that indicates the financial materiality of the lawsuit shown by the company $\mathrm{i}$, in the period $\mathrm{t}$;

INST1 ${ }_{i t}$ dummy: binary of the lawsuit in the first instance of the company $\mathrm{i}$, in the period $\mathrm{t}$;

INST2 ${ }_{i t}$ dummy: binary of the lawsuit in the second instance of the company $\mathrm{i}$, in the period $\mathrm{t}$;

INST3 ${ }_{i t}$ dummy: binary of the lawsuit in the third instance of the company $\mathrm{i}$, in the period $\mathrm{t}$;

INSTSUP ${ }_{i t}$ dummy: binary of the lawsuit in the superior instance of the company $\mathrm{i}$, in the período $\mathrm{t}$

$\varepsilon_{i t}:$ term of regression error.

The software Stata ${ }^{\circledR}$, version 2013, was used for the statistical analysis, to perform the statistical technique of logistic regression with panel data.

\section{RESULTS ANALYSIS}

A total of 11,200 lawsuit observations were collected, of which 6,194 observations were used, representing the 2,058 cases disclosed in more than one period, presenting 228 occurrences of changes in the chance of loss in the period 2010-2016. For the statistical model, the lawsuit information disclosed in more than one period were the ones considered, since the dependent variable is the change in the probability of loss. Table 2 shows the variance decomposition analysis of the quantitative variables that shows the variation over time for each lawsuit (within) and the variation between them (between). 
Table 2. Statistics of quantitative variables and decomposition of variance within and between

\begin{tabular}{|c|c|c|c|c|c|c|}
\hline Variables & Decomposition & Average & Standard Deviation & Minimum & Maximum & Observations \\
\hline \multirow{3}{*}{ Amount_ln } & general & & 2.748693 & 5.7 & 24.39 & $\mathrm{~N}=6194$ \\
\hline & between & 15.65594 & 2.791882 & 6.03 & 23.65143 & $\mathrm{n}=2058$ \\
\hline & within & & 0.4581858 & 4.76594 & 21.60927 & $\mathrm{~T}-\mathrm{bar}=3.00972$ \\
\hline \multirow{3}{*}{ Internat } & general & & 0.0766013 & 0 & 0.596 & $N=6194$ \\
\hline & between & 0.018135 & 0.0737216 & 0 & 0.567 & $\mathrm{n}=2058$ \\
\hline & within & & 0.0183235 & -0.1958654 & 0.1988847 & $\mathrm{~T}-\mathrm{bar}=3.00972$ \\
\hline \multirow{3}{*}{ Time } & general & & 6.137605 & 0 & 51 & $\mathrm{~N}=6194$ \\
\hline & between & 6.603972 & 5.866055 & 0 & 51 & $\mathrm{n}=2058$ \\
\hline & within & & 1.910762 & -19.79603 & 22.60397 & $\mathrm{~T}-\mathrm{bar}=3.00972$ \\
\hline \multirow{3}{*}{ Result } & general & & 12.36253 & -88.54 & 121.92 & $\mathrm{~N}=6194$ \\
\hline & between & 0.080358 & 6.909157 & -58.825 & 57.84 & $\mathrm{n}=2058$ \\
\hline & Within & & 10.24282 & -74.66214 & 83.41702 & T-bar $=3.00972$ \\
\hline \multirow{3}{*}{ Size } & general & & 1.641702 & 14.43 & 27.53 & $\mathrm{~N}=6194$ \\
\hline & between & 22.26417 & 1.618792 & 16.14333 & 27.53 & $\mathrm{n}=2058$ \\
\hline & within & & 0.5583489 & 19.45417 & 25.07417 & T-bar $=3.00972$ \\
\hline
\end{tabular}

Source: Research data.

The standard deviations of the average of the regressors help to identify that the variation between the lawsuit is greater than the variation over time (within), except for the explanatory variable variation of the result. Thus, fixed-effects estimators, as they depend on temporal result, may not be adequate. The random effects model, which is a weighted average of between and within variations seems to be the best option. Table 3 presents the frequencies and percentages of the binary variables, considering the variation between and within.

According to the general category, 228 lawsuits changed the probability of loss in the period from 2010 to 2016 , which represents a percentage of $33.52 \%$ over time. In the between category, the smallest observations regarding presence are in the variables related to the type of regulatory lawsuit and instances 3 and superior. 
Table 3. Tabulation within and between binary variables

\begin{tabular}{|c|c|c|c|c|c|c|}
\hline \multirow{2}{*}{\multicolumn{2}{|c|}{ Variables }} & \multicolumn{2}{|c|}{ General } & \multicolumn{2}{|c|}{ Between } & \multirow{2}{*}{$\begin{array}{c}\text { Within } \\
\text { Percentage }\end{array}$} \\
\hline & & Frequency & Percentage & Frequency & Percentage & \\
\hline \multirow{3}{*}{ Change } & 0 & 5966 & 96.32 & 2057 & 99.95 & 96.81 \\
\hline & 1 & 228 & 3.68 & 199 & 9.67 & 33.52 \\
\hline & Total & 6194 & 100 & 2256 & 109.62 & 91.22 \\
\hline \multirow{3}{*}{ Material. } & 0 & 3065 & 49.49 & 1215 & 59.04 & 90.63 \\
\hline & 1 & 3128 & 50.51 & 1025 & 49.81 & 93.35 \\
\hline & Total & 6193 & 100 & 2240 & 108.84 & 91.88 \\
\hline \multirow{3}{*}{ ADR } & 0 & 5484 & 88.54 & 1829 & 88.87 & 99.78 \\
\hline & 1 & 710 & 11.46 & 235 & 11.42 & 99.18 \\
\hline & Total & 6194 & 100 & 2064 & 100.29 & 99.71 \\
\hline \multirow{3}{*}{$\mathrm{CG}$} & 0 & 5048 & 81.5 & 1681 & 81.68 & 100 \\
\hline & 1 & 1146 & 18.5 & 377 & 18.32 & 100 \\
\hline & Total & 6194 & 100 & 2058 & 100 & 100 \\
\hline \multirow{3}{*}{ Regul. } & 0 & 944 & 15.24 & 293 & 14.24 & 100 \\
\hline & 1 & 5250 & 84.76 & 1765 & 85.76 & 100 \\
\hline & Total & 6194 & 100 & 2058 & 100 & 100 \\
\hline \multirow{3}{*}{ Audit } & 0 & 4697 & 75.83 & 2042 & 99.22 & 76.59 \\
\hline & 1 & 1497 & 24.17 & 1317 & 63.99 & 37.51 \\
\hline & Total & 6194 & 100 & 3359 & 163.22 & 61.27 \\
\hline \multirow{3}{*}{$\mathrm{Lab}$} & 0 & 5178 & 83.6 & 1707 & 82.94 & 99.95 \\
\hline & 1 & 1016 & 16.4 & 353 & 17.15 & 99.67 \\
\hline & Total & 6194 & 100 & 2060 & 100.1 & 99.9 \\
\hline \multirow{3}{*}{ Tax } & 0 & 3329 & 53.75 & 1152 & 55.98 & 100 \\
\hline & 1 & 2865 & 46.25 & 906 & 44.02 & 100 \\
\hline & Total & 6194 & 100 & 2058 & 100 & 100 \\
\hline \multirow{3}{*}{ Env } & 0 & 5937 & 95.85 & 1970 & 95.72 & 100 \\
\hline & 1 & 257 & 4.15 & 88 & 4.28 & 100 \\
\hline & Total & 6194 & 100 & 2058 & 100 & 100 \\
\hline \multirow{3}{*}{ Civ } & 0 & 4552 & 73.49 & 1513 & 73.52 & 99.88 \\
\hline & 1 & 1642 & 26.51 & 548 & 26.63 & 99.79 \\
\hline & Total & 6194 & 100 & 2061 & 100.15 & 99.85 \\
\hline \multirow{3}{*}{ Reg } & 0 & 6089 & 98.3 & 2022 & 98.25 & 100 \\
\hline & 1 & 105 & 1.7 & 36 & 1.75 & 100 \\
\hline & Total & 6194 & 100 & 2058 & 100 & 100 \\
\hline \multirow{3}{*}{ Inst1 } & 0 & 4287 & 69.21 & 1494 & 72.59 & 96.07 \\
\hline & 1 & 1907 & 30.79 & 698 & 33.92 & 89.22 \\
\hline & Total & 6194 & 100 & 2192 & 106.51 & 93.89 \\
\hline \multirow{3}{*}{ Inst2 } & 0 & 5249 & 84.74 & 1846 & 89.7 & 96.44 \\
\hline & 1 & 945 & 15.26 & 344 & 16.72 & 80.75 \\
\hline & Total & 6194 & 100 & 2190 & 106.41 & 93.97 \\
\hline \multirow{3}{*}{ Inst3 } & 0 & 6081 & 98.18 & 2028 & 98.54 & 99.6 \\
\hline & 1 & 113 & 1.82 & 48 & 2.33 & 79.3 \\
\hline & Total & 6194 & 100 & 2076 & 100.87 & 99.13 \\
\hline \multirow{3}{*}{ Instsup } & 0 & 6056 & 97.77 & 2030 & 98.64 & 99.54 \\
\hline & 1 & 138 & 2.23 & 49 & 2.38 & 76.31 \\
\hline & Total & 6194 & 100 & 2079 & 101.02 & 98.99 \\
\hline
\end{tabular}


Correlation matrix demonstrates that the highest correlations found among the explanatory variables are 0.5619 between size and ADR, and 0.5075 between size and amount ln. However, it was decided to keep all variables, excluding some of them if necessary. The other correlations are lower than this amount and considered low, which is an indication that the model does not present problems of multicollinearity. The logistic regression was then tested, and the change in the probability of loss of the lawsuit is the dependent variable to be explained through the independent variables. The results of the regressions are presented in Table 4.

Table 4. Random effect logit panel model

\begin{tabular}{lcccccc}
\hline \multicolumn{1}{c}{ Change } & Coefficient & Odds & Standard Error & \multicolumn{2}{c}{ Sig. } & \\
\hline Amount_Ln & 0.129321 & 1.129768 & 0.037191 & 0.001 & $* * *$ \\
Materiality & 0.940501 & 2.496114 & 0.184281 & 0.000 & $* * *$ \\
Adr & 0.469819 & 1.574945 & 0.256503 & 0.067 & $*$ \\
CG & 0.383975 & 1.449416 & 0.198923 & 0.054 & $*$ \\
Internat & 0.118129 & 1.200471 & 1.038279 & 0.909 & \\
Regulation & -0.02294 & 1.019647 & 0.235844 & 0.923 & \\
Audit & 0.363487 & 1.402451 & 0.164972 & 0.028 & $* *$ \\
Labor & 1.182302 & 3.177439 & 0.648073 & 0.068 & $*$ \\
Tax & -0.04069 & 1.032224 & 0.636278 & 0.949 & \\
Env & 1.64549 & 4.933166 & 0.679435 & 0.015 & $* *$ \\
Civil & 1.118781 & 3.045081 & 0.644044 & 0.082 & $*$ \\
Regul & 0.641296 & 1.886462 & 0.905834 & 0.479 & \\
Inst1 & -0.80011 & 0.4619556 & 0.19834 & 0.000 & $* * *$ \\
Inst2 & -0.15128 & 0.8390644 & 0.209999 & 0.471 & \\
Inst3 & 0.51389 & 1.682053 & 0.367326 & 0.162 & \\
Instsup & -1.56564 & 0.2251829 & 0.644324 & 0.015 & $* *$ \\
Time & 0.022505 & 1.021497 & 0.012652 & 0.075 & $*$ \\
Result & 0.002019 & 1.001679 & 0.006246 & 0.747 & \\
Size & -0.11439 & 0.8945816 & 0.065751 & 0.082 & $*$ \\
Cons & -4.43641 & 0.0157642 & 1.378994 & 0.001 & $* * *$ \\
\hline Observations & & 6193 & & Wald chi ${ }^{2}$ & 123.45 & \\
Log likelihood & -895.241 & Prob $>$ chi $^{2}$ & 0.0000 & \\
\hline Soure: Res & & & & &
\end{tabular}

Source: Research data.

Obs.: *, ** and $* * *$ correspond to $10 \%, 5 \%$ and $1 \%$ of significance level, respectively.

In order to improve the model, the stepwise command was used, removing the non-significant variables. Regarding the level of significance, the outcome remained unchanged.

Nineteen hypotheses were proposed in the model, of which 11 were used: $\mathrm{H}_{1}, \mathrm{H}_{2 \mathrm{a}}, \mathrm{H}_{4}, \mathrm{H}_{7 \mathrm{a}}, \mathrm{H}_{7 \mathrm{c}}, \mathrm{H}_{7 \mathrm{~d}}, \mathrm{H}_{8}, \mathrm{H}_{9}$, $\mathrm{H}_{10}, \mathrm{H}_{11 \mathrm{a}}$ e $\mathrm{H}_{11 \mathrm{~b}}$. The variables amount_ln, Materiality and Inst1 presented a significance level of 1\%. The first two variables have a respective odds ratio of $12.97 \%$ and $149.61 \%$, which shows that the value of the lawsuit and the possible financial impact analyzed by the companies through materiality are among the characteristics that affect the change in the probability of loss. On the other hand, variable first instance presented a negative coefficient, and has a $46,19 \%$ chance of not occurring, which was already expected, because the first instance is the initial phase (discussion) of the lawsuit.

The Instsup variable presented a significance of 5\% and a negative relationship, which indicates that $77.49 \%$ of the proceedings in this instance tend to change the chance of loss, which confirms the research hypothesis that all propositions in the lawsuit are the same. It is time to await the procedural decision. The coefficients of the variables audit and environmental lawsuit showed a 5\% level, presented a significance level of 5\% and a positive relation. The results corroborate Ribeiro, Ribeiro, and Weffort (2013), showing that the change of the audit firm influences the decision-making process on the classification of the probability of loss, considering that auditors play a fundamental role with the manager or accountant when validating the classification on administrative, judicial and arbitration proceedings. 
We highlighted for the environmental lawsuit, as it increases the rate of change in the probability of loss by $393.31 \%$, the highest percentage found among significant variables. The significance related to environmental lawsuits can be explained by the pressures on environmental and sustainability issues, whose actions go beyond the cost barrier and involve the company's image and operations since some actions prevent the company from continuing activities while there are pending lawsuits. The negative coefficient of the variable 'superior instance' was expected, because at this level the lawyers have already addressed what is possible to discuss and are awaiting the decision, which means that there is no reason to change the probability of loss.

The coefficients of the variables ADR, labor and civil types of lawsuit, and the duration of the lawsuit presented a significance level of $10 \%$, showing a positive relation, and the odds to influence the change in the probability of loss of the lawsuits of $57.49 \%, 217.74 \%, 204.50 \%$ and $2.14 \%$, respectively. A company issuing ADR has a differential because it needs to conform to the demanding resolutions requested by the American market. In this company, labor and civil lawsuits are more likely to be found. The labor lawsuits have legislation focused on workers' rights, and the civil ones refer to daily operational issues. Differently from the tax lawsuits that originate from legal disputes, Ribeiro, Ribeiro, and Weffort (2013) explain that these lawsuits started in the period of high inflation rates in Brazil. In this period the government economic packages to lower inflation provoked controversies about the constitutionality of the measures, and even after the end of this period, companies continued to seek amnesty and to reduce taxes and fines referring to that time.

Although the lawsuit duration is statistically significant and indicates that it influences the change in the likelihood of loss in the lawsuits, since the longer the discussion, the more notes about the lawsuit emerge and, therefore, facilitating the understanding of the subject in debate and the probability of loss has a chance of occurring, 2.14\%. Even though the coefficient of the variable size is statistically significant, it presented a negative relation, contrary to what was expected, since the general understanding is that larger companies would have more resources and could better estimate the probability. The marginal effect obtained by the respective variable was 0.8945 , that is, larger companies have a $10.55 \%$ lower odds ratio than smaller companies, in relation to the likelihood of change in the odds of losing the lawsuits.

\section{FINAL CONSIDERATIONS}

Analyzing company risk is a challenge for stakeholders, especially when operations are off-balance sheet. To identify the characteristics that affect the change in the probability of loss, the study used the longitudinal analysis of the logistic regression with panel data.

The statistically significant variables of the logistic panel of random effects showed that the characteristics of the lawsuits influence the change in the probability of loss. This corroborates Gonzalez and Silva Filho (2016, p.9) who stated that the analysis of the litigations' legal risk needs to take into consideration the "legal particularities of each case, for example: the factual and evidential elements, the subject to be defended, the jurisprudence on the subject under discussion, etc.". The significant variables also showed that the characteristics of the companies affect the change in the probability of loss.

Among the statistically significant variables of the logistic panel of random effects, Inst1, InstSup, and size presented a negative coefficient indicating that these lawsuits that are in the first instance are more likely than not to change the probability of loss, perhaps because they are in the initial stages of the discussion. Moreover, the fact that lawsuits tend not to change when they are already in superior instances may be due to the resolution of the most imminent case. The size of the company indicates that the larger the company, the smaller the chance to change the probability of loss of the lawsuit.

The variables of the same model with positive coefficients were: amount of the lawsuit and the financial materiality, both at the level of 1\% significance; exchange of audit firm and environmental lawsuits at the level of 5\%; companies that issue ADRs, participants in the new market, with labor and civil lawsuits, with more duration of lawsuit, with the level of significance of $10 \%$. This indicates that the presence of these variables may explain the change in the probability of loss of the lawsuit where the Brazilian companies are part.

Understanding the variables that influence the change in the odds of losses allows stakeholders to project future cash flows and potential impacts on profit or loss. It is important to highlight that the change of a contingent liability to provision (or vice versa) may influence decision making, for example: to carry out a business combination, to decide to invest in a company, or to open a business (e.g. a new business), in restrictive convent clauses, indicators such as debt, profitability and cash flows of the company. Similar to Holder, Karim and Woods (2013), our contributions made should be of wide interest of IASB's discussion of off-balance sheet operations related to contingencies, also, given the importance of the subject pointed out by Daniels and Flesher (1991). 
Regarding the limitations of the research, there was a lack of standardization of information in the Reference Form (RF). As for recommendations for future research, it is suggested to work with the provisions and contingencies in the company's result showing their material effect.

\section{REFERENCES}

Baptista, E. (2009). Ganhos em transparência versus novos instrumentos de manipulação: o paradoxo das modificações trazidas pela lei no 11.638. Revista de Administração de Empresas, 49(2), 234-239. DOI: http:// dx.doi.org/10.1590/S0034-75902009000200009.

Blacconiere, W. G., \& Patten, D. M. (1994). Environmental disclosures, regulatory costs, and changes in firm value. Journal of accounting and economics, 18(3), 357-377. DOI: https://doi.org/10.1016/0165-4101(94)90026-4.

Castro, M. C. C. S., Vieira, L. K., \& Pinheiro, L. E. T. (2015). Comparação do Disclosure de Contingências Ativas e Passivas nas Empresas Brasileiras com Ações Negociadas na BM\&FBOVESPA e na NYSE. Revista de Contabilidade do Mestrado em Ciências Contábeis da UERJ, 20(2), 49-65.

Capriotti, K., \& Waldrup, B. E. (2005). Miscommunication of uncertainties in financial statements: a study of preparers and users. Journal of Business \& Economics Research, 3(1), 33-46. DOI: https://doi.org/10.19030/ jber.v3i1.2733.

Comitê, D. P. C. C. (2005). Pronunciamento Técnico CPC 25: Provisões. Passivos Contingentes e Ativos Contingentes. Brasília, DF.

Daniels, R., \& Flesher, D. L. (1991). The Chicago, Rock Island and Pacific Railroad Company: an examination of contingent liabilities of 1903-1904. Accounting Historians Journal, 18(1), 55-73. DOI: https://doi. org/10.2308/0148-4184.18.1.55.

Doupnik, T. S., \& Richter, M. (2004). The impact of culture on the interpretation of "in context" verbal probability expressions. Journal of International Accounting Research, 3(1), 1-20. DOI: https://doi.org/10.2308/ jiar.2004.3.1.1.

Du, N., \& Stevens, K. (2011). Numeric-to-verbal translation of probability expressions in SFAS 5. Managerial Auditing Journal, 26(3), 248-262. DOI: https://doi.org/10.1108/02686901111113190.

EAE Business School. (n.d.). Recuperado em Agosto, 08, 2018 de: https://www.eaeprogramas.es/ internacionalizacion/brasil-como-economia-emergente.

Farias, M. R. S. (2006). Bases conceituais e normativas para reconhecimento e divulgação do passivo contingente: um estudo empírico no setor químico e petroquímico brasileiro. In: 6o. Congresso USP de Controladoria e Contabilidade. São Paulo. Anais.

Firth, M. (1979). The impact of size, stock market listing, and auditors on voluntary disclosure in corporate annual reports. Accounting and Business research, 9(36), 273-280. DOI: https://oi.org/10.1080/00014788.1979.9 729168.

Gelbcke, E. R., Santos, A. D., Iudícibus, S. D., \& Martins, E. (2018). Manual de contabilidade societária: aplicável a todas as sociedades de acordo com as normas internacionais e do CPC.

Gleason, C. A., \& Mills, L. F. (2002). Materiality and contingent tax liability reporting. The Accounting Review, $77(2), 317-342$.

Gonzalez, E. Z., \& da Silva Filho, C. F. (2016). 02) Risco Legal e Companhias Abertas: Ponderações Sobre a Importância da Avaliação do Risco Jurídico para Atuação no Mercado Mobiliário. Revista Brasileira de Gestão e Engenharia - RBGE, (14), 20-37.

Hennes, K. M. (2014). Disclosure of contingent legal liabilities. Journal of Accounting and Public Policy, 33(1), 32-50. DOI: https://doi.org/10.1016/j.jaccpubpol.2013.10.005.

Holder, A. D., Karim, K. E., Lin, K. J., \& Woods, M. (2013). A content analysis of the comment letters to the FASB and IASB: Accounting for contingencies. Advances in Accounting, 29(1), 134-153. DOI: https://doi. org/10.1016/j.adiac.2013.03.005.

Jensen, M. C., \& Meckling, W. H. (1976). Theory of the firm: Managerial behavior, agency costs and ownership structure. Journal of financial economics, 3(4), 305-360. DOI: https://doi.org/10.1016/0304405X(76)90026-X. 
Jesus, S. S. de, \& Souza, M. M. de. (2016). Impacto do reconhecimento dos passivos contingentes na situação econômica das empresas brasileiras auditadas pelas big four. Revista de Contabilidade da UFBA, 10(2), 4363.

Lima, B. R. T. De, Menezes Junior, C. B. De \& Rodrigues, J. M. (2017). Disclosure de Provisões, Passivos Contingentes e Ativos Contingentes Relacionados aos Precedentes Judiciais Vinculantes. In: $3^{\circ}$ Congresso UNB de Contabilidade e Governança. Anais. Brasília-DF.

Losekann, V. L., dos Reis Lehnhart, E., \& Pereira, R. (2018). Impacto esperado sobre o patrimônio líquido de reavaliações de provisões para contingências, de remota para possível e de possível para provável. Revista de Contabilidade da UFBA, 12(1), 250-270.

Macedo, F. (2018, maio, 08). A falta de segurança jurídica atrasa o Brasil. O Estadão. Recuperado em Agosto, 28, 2018, de https://politica.estadao.com.br/blogs/fausto-macedo/a-falta-de-seguranca-juridica-atrasa-o-brasil/

Moreira, M. L. (2013). Beta contábil X Beta CAPM: um estudo com as empresas dos setores regulados e não regulados listados na BM\&FBovespa. 92 p. Dissertação (mestrado) - Universidade Federal do Ceará, Faculdade de Economia, Administração, Atuária e Contabilidade, Mestrado Profissional em Administração e Controladoria, Fortaleza-CE, 2013.

Nelson, M.W., Kinney Jr., W.R. (1997), The effect of ambiguity on loss contingency reporting judgments. Accounting Review, 72(2), 257-274.

Piccioni, J. L.; Sheng, H. H.; Lora, M I. (2012). Mutual fund managers stock preferences in Latin America. International Review of Financial Analysis, (24), 38-47. DOI: https://doi.org/10.1016/j.irfa.2012.07.003.

Prado, F. J. do. (2014). Análise do comportamento da divulgação das informações sobre provisões e passivos contingentes das empresas do setor de energia elétrica listadas na BM\&FBOVESPA.104f. Dissertação de Mestrado. Universidade de São Paulo, São Paulo-SP.

Ribeiro, A. de C.; Ribeiro, M. de S.; Weffort, E. F. J. (2013). Provisões, contingências e o pronunciamento CPC 25: as percepções dos protagonistas envolvidos. Revista Universo Contábil. (9)3, 38-54. DOI: https://doi. org/10.4270/RUC.2013321.

Rosa, C. A. da. (2014). Panorama e reconfiguração das contingências passivas no Brasil. 112f. Dissertação de Mestrado, Programa de Pós-Graduação em Contabilidade, Universidade Federal de Santa Catarina, Florianópolis, SC.

Santana, B. R. dos S. (2013). Operações off-balance sheet e instrumentos híbridos: utilização pelas empresas que compõe o IBrX-100 e sua relação com o rating e a internacionalização das empresas brasileiras. $38 \mathrm{f}$. Dissertação de Mestrado. Escola de Economia de São Paulo, São Paulo-SP.

Silveira, A. D. M. da; Barros, L. A. B. de C. (2008). Determinantes da qualidade da governança corporativa das companhias abertas brasileiras. REAd-Revista Eletrônica de Administração, (14)3.

Teixeira, C.; Silva, A. F. (2009). The interpretation of verbal probability expressions used in the IAS/IFRS: some Portuguese evidence. Revista de Estudos Politécnicos, (12), 57-73.

\section{Como citar este artigo}

Ferreira, J. da S., \& Rover, S. (2019). An analysis of the relevant lawsuits in Brazilian companies: characteristics that influence the change in the probability of loss provision and contingent liabilities. Revista de Contabilidade e Organizações, 13:e155596. DOI: http://dx.doi.org/10.11606/issn.1982-6486. rco.2019.155596 


\section{APPENDIX}

Table 1 presents the research sample by sector.

Table 1. Research sample

\begin{tabular}{lc}
\hline \multicolumn{1}{c}{ Analyzed companies } & Number of companies \\
\hline (+) Oil, gas and biofuel sector & 11 \\
(+) Non-cyclical consumption sector & 24 \\
(+) Public utility sector & 24 \\
Total & 59 \\
\hline Source: B3 S.A. - Brasil, Bolsa Balcão (2017).
\end{tabular}

Table 2 shows the items of the RF which relate to Risk Factors.

Table 2. Items of the Reference Form used in the research

\begin{tabular}{cl}
\hline Item of RF & Item description \\
\hline 4.3 & Non-confidential and relevant judicial, administrative, or arbitral lawsuits. \\
4.4 & $\begin{array}{l}\text { Non-confidential judicial, administrative, or arbitral lawsuits where the parties are administrators, } \\
\text { ex-administrators, controlling shareholder, former controlling shareholder, or investors. }\end{array}$ \\
4.5 & $\begin{array}{l}\text { Relevant confidential lawsuits. } \\
\text { Judicial, administrative, or arbitral lawsuits that are repetitive or connected, and non-confidential and } \\
\text { relevant together. }\end{array}$ \\
& Other relevant contingencies \\
\hline Source: B3 S.A. - Brasil, Bolsa Balcão (2017).
\end{tabular}


Table 3. Correlation matrix between variables

\begin{tabular}{|c|c|c|c|c|c|c|c|c|c|c|c|c|c|c|c|c|c|c|c|c|}
\hline & Change & Amount & Mat & ADR & $\mathrm{NM}$ & Int. & Regul. & Audit. & Lab. & Tax. & Env. & Civ. & Reg. & Inst1 & Inst2 & Inst3 & InstS & Time & Var & Size \\
\hline Change & 1.000 & & & & & & & & & & & & & & & & & & & \\
\hline Amount & 0.053 & 1.000 & & & & & & & & & & & & & & & & & & \\
\hline Mat & 0.086 & 0.134 & 1.000 & & & & & & & & & & & & & & & & & \\
\hline $\mathrm{ADR}$ & 0.040 & 0.394 & 0.073 & 1.000 & & & & & & & & & & & & & & & & \\
\hline NM & 0.048 & 0.076 & 0.277 & 0.182 & 1.000 & & & & & & & & & & & & & & & \\
\hline Int. & 0.006 & 0.155 & 0.109 & 0.039 & 0.344 & 1.000 & & & & & & & & & & & & & & \\
\hline Regul. & -0.001 & 0.033 & -0.153 & -0.042 & -0.373 & -0.271 & 1.000 & & & & & & & & & & & & & \\
\hline Audit. & 0.014 & 0.007 & -0.022 & -0.061 & -0.070 & -0.085 & 0.105 & 1.000 & & & & & & & & & & & & \\
\hline Lab. & 0.029 & -0.331 & 0.144 & -0.118 & 0.058 & -0.015 & -0.004 & -0.023 & 1.000 & & & & & & & & & & & \\
\hline Tax. & -0.073 & 0.266 & -0.102 & 0.060 & 0.002 & 0.090 & -0.134 & 0.051 & -0.411 & 1.000 & & & & & & & & & & \\
\hline Env. & 0.071 & 0.134 & -0.034 & 0.136 & 0.114 & 0.000 & 0.021 & -0.034 & -0.092 & -0.193 & 1.000 & & & & & & & & & \\
\hline Civ. & 0.044 & 0.039 & 0.127 & -0.019 & -0.036 & -0.058 & 0.082 & 0.041 & -0.266 & -0.557 & -0.125 & 1.000 & & & & & & & & \\
\hline Reg. & -0.006 & 0.003 & -0.038 & 0.102 & -0.043 & -0.017 & 0.056 & -0.016 & -0.058 & -0.122 & -0.027 & -0.079 & 1.000 & & & & & & & \\
\hline Inst1 & -0.015 & -0.055 & 0.331 & 0.013 & 0.144 & 0.007 & -0.136 & 0.014 & 0.112 & -0.208 & -0.035 & 0.224 & 0.026 & 1.000 & & & & & & \\
\hline Inst2 & 0.029 & 0.068 & 0.196 & 0.038 & 0.095 & -0.006 & -0.109 & 0.034 & -0.053 & 0.062 & -0.005 & 0.005 & 0.070 & -0.283 & 1.000 & & & & & \\
\hline Inst3 & 0.057 & 0.017 & 0.046 & -0.004 & 0.059 & -0.005 & 0.044 & -0.001 & 0.086 & -0.061 & 0.026 & -0.022 & 0.076 & -0.091 & -0.058 & 1.000 & & & & \\
\hline InstS & -0.012 & 0.076 & 0.047 & 0.155 & -0.044 & -0.011 & -0.036 & -0.029 & 0.019 & -0.090 & 0.013 & 0.095 & 0.006 & -0.101 & -0.064 & -0.021 & 1.000 & & & \\
\hline Time & 0.076 & 0.093 & 0.368 & 0.082 & 0.043 & -0.019 & -0.036 & -0.081 & 0.202 & -0.319 & 0.090 & 0.259 & 0.037 & 0.127 & 0.205 & 0.066 & 0.197 & 1.000 & & \\
\hline Var & -0.016 & 0.057 & -0.189 & -0.019 & 0.014 & 0.014 & 0.077 & 0.064 & -0.093 & 0.143 & -0.003 & -0.114 & -0.074 & -0.080 & -0.122 & -0.026 & -0.014 & -0.184 & 1.000 & \\
\hline Size & 0.046 & 0.508 & 0.227 & 0.562 & 0.229 & 0.234 & 0.011 & 0.096 & -0.075 & -0.039 & 0.160 & 0.173 & 0.099 & 0.099 & 0.067 & 0.051 & 0.145 & 0.229 & -0.017 & 1.000 \\
\hline
\end{tabular}

Source: Research data. 